DOI: 10.17707/AgricultForest.61.3.02

\author{
Mohsen JANMOHAMMADI*, \\ Naser SABAGHNIA, Amin AHADNEZHAD ${ }^{1}$
}

\title{
IMPACT OF SILICON DIOXIDE NANOPARTICLES ON SEEDLING EARLY GROWTH OF LENTIL (LENS CULINARIS MEDIK.) GENOTYPES WITH VARIOUS ORIGINS
}

\begin{abstract}
SUMMARY
Quick seed germination and stand establishment are significant factors to lentil production under saline soil of arid and semi-arid regions. The application of beneficial nanoparticles during the seed germination has shown a new field of nano-agriculture. The current study was aimed at investigating the potential influences of nano-silicon dioxide (at 1 and $2 \mathrm{mM}$ concentration) on seed germination of lentil (Lens culinaris Medik.) genotypes with different geographical origins under a range of $\mathrm{NaCl}$ concentrations (i.e. 0, 50, 100 and $150 \mathrm{mM}$ ). Results showed that germination significantly delayed by increasing salt stress. However, the rate of decline was variable among the genotypes. Application of $1 \mathrm{mM}$ silicon dioxide nanoparticles $\left(\mathrm{nSiO}_{2}\right)$ could considerably alleviate the adverse effect of salt stress on germination percentage, root and shoot length, seedling weight, mean germination time, seedling vigour index and cotyledon reserve mobilization. The suppressive impact with higher $\mathrm{nSiO}_{2}$ concentration $(2 \mathrm{Mm})$ shows the need for cautious application of these particles during seed germination. The best performance was recorded for genotypes originated from Mexico, Syria and Jordan (PI 299127, Syrian Local Large, 78S 26013). Our results suggest that $\mathrm{nSiO}_{2}$ has favorable effect on lentil seed germination under salinity stress and it can be economic to use suitable concentration of this nanoparticle in the production system under saline conditions.
\end{abstract}

Keywords: early seedling growth; germination rate; nano-silica; salinization; vigour

\section{INTRODUCTION}

Salinity is an imperative stress that significantly restricts plant growth and productivity. It has been estimated that at least $20 \%$ of all irrigated lands are affected by salinity stress. The total global area of salt-affected soils has been approximated to be about 830 million hectares (Martinez-Beltran and Manzur, 2005). Salinity has a critical influence on the seeds germination of and plant establishment. Seed germination is an important process in plant growth to

\footnotetext{
1 Mohsen Janmohammadi, (corresponding author e-mail jmohamad@alumni.ut.ac.ir), Naser Sabaghnia, Amin Ahadnezhad, Department of Agronomy and Plant Breeding, Agriculture College, University of Maragheh, IRAN.

Note: The authors declare that they have no conflicts of interest. Authorship Form signed online.
} 
achieve optimal seedling number and acceptable plant density that result in high seed yield. Seed germination and seedling growth of lentil (Lens culinaris L.) similar to other crops were adversely influenced through salinity stress (Katerji et al., 2001; El-Monem and Sharaf, 2008). Fast and uniform seed germination as well as early seedling establishment are important factors for crop production under salt-stress conditions. Seed germination and early seedling growth stage are typically more susceptible than other plant growth stages to salt stress and it has been indicated that plant salt tolerance usually increases with plant ontogeny because seed germination usually occurs in the uppermost soil layers where soluble salts accumulate as a result of evaporation and capillary rise. Salt stress can postpone the initiation, decrease the rate, and enhance the temporal distribution of germination, leading to a significant decline in plant development and crop yield (Ashraf and Foolad, 2005).

Lentil is an important annual winter/summer grain legume cultivated in the semi-arid regions of WANA (West Asia and North Africa) district (Gürsoy et al., 2014), where the drought and salinity stresses are undoubtedly the most important environmental problems limiting the productivity of lentil. In this area rainfall is relatively low and increased use of saline or marginal quality water for irrigation caused to elevated chloride content in soil. Soil/water salinity may result in poor and unsynchronized seedling emergence. It seems that shortening the time between planting and emergence may be able to protect seeds from deleterious effect of salinity stress. In this context, it is appearing that some presowing seed treatment and exogenous application of ex vivo synthesized nanoparticles (NPs) may be able to alleviate the adverse effect of the abiotic stress on germination (Ashraf and Foolad, 2005; Wang et al., 2011; Janmohammadi, 2012). Between the nanoparticles, nanosilica $\left(\mathrm{nSiO}_{2}\right)$ has gained greater consideration during the last years. Silicon is plentiful in soils and the second most common element on earth after oxygen and has been recognized as a beneficial nutrient for plant growth and development. A number of researchers have reported the advantageous role of silicon on seed germination and seedling development under stress situation (Ma, 2004; Ma, Yamaji, 2006; Liang et al., 2007; Wang et al., 2010; Sabaghnia and Janmohammadi, 2014). It seems that silicon has a prominent function in plat protection against biotic and abiotic stress (Ma, 2004). It has been reported that silicon application could alleviate the adverse effects of salinity stress on seed germination (Haghighi et al., 2012) and increased water-use efficiency and photosynthesis rate in plants (Ma, 2004). Nevertheless, the absorption of silicon by seed is of major significance and it is essential to find the ways of enhancing the uptake of accessible silicon through novel techniques. The recent progresses in nanotechnology and its application in the field of agriculture are surprisingly growing; consequently, it is attractive to recognize the role of nano-silicon dioxide $\left(\mathrm{nSiO}_{2}\right)$ in the germination of seeds and seedling early growth. In particular, silica-based NPs have collected interest as a micronutrient involved in mitigation of salinity stress during seed germination. 
Additionally, one the main management issues involved in lentil production in saline area is selection of genotypes adapted to the salinity level of the soil. Although adaptability and stability of some lentil (Lens culinaris) landraces under a wide range of variable environments has been evaluated (AlAysh et al., 2014), there are no comprehensive information about the genotypic response of lentil to salt stress during the seedling early growth. Selection for salinity resistance appears as a tiresome work and plant breeders are, consequently, looking for rapid, inexpensive and reliable ways to evaluate the salt-resistance of selected material. It seems that assessment of seed germination and early seedling growth in-vitro under different salt concentrations could be as a relatively quick method of selection.

Although there are some of literatures regarding interaction among salt stress and silicon in higher plants, there is no comprehensive information about the feasible advantageous influences silicon dioxide nanoparticles application to reduce salt stress damages during the lentil seed germination. In our work we studied the responses of some local genotype of lentil (Lens culinaris Medic.) to application of silicon dioxide -based NPs under different levels of salt stress.

\section{MATERIAL AND METHODS}

Seeds of seven genotypes of lentil (Lens culinaris Medik.) with different origin including of PI 299127 (Mexico, G1), PI 339319 (Turkey, G2), L 1278 (India, G3), Syrian Local Large (Syria, G4), Precoz (Argentina, G5), 78S 26013 (Jordan, G6) and local check (Iran, G7) were used in this study. Primary seed moisture content was $9.61 \%$. Seeds of uniform size were used in the experiment. Lentil seeds were sterilized with hypochlorite before germination test. Thirty sterilized seeds of each genotype were transferred onto the two sheets of filter papers inside the petri dishes and germination evaluated at $20 \pm 1{ }^{\circ} \mathrm{C}$ in a dark growth chamber with $45 \%$ relativity humidity. The experimental design was three factors factorial $(7 \times 4 \times 3)$ arranged in a completely randomized design (CRD) with three replications. First factor was genotype, the second salinity level and third was nano-silicon dioxide concentrations. Seeds were germinated under three $\mathrm{NaCl}$ concentrations $(50,100$ and $150 \mathrm{mM})$ and a control (distilled water). Nano-silicon dioxide was procured from Nanomaterials Pioneers, Iran, and was applied at three concentrations $(0,1$ and $2 \mathrm{mM})$ at the onset of germination test. It has an average primary particle size of $20-30 \mathrm{~nm}$ with a corresponding surface area of $180-600 \mathrm{~m}^{2} / \mathrm{g}$. The result of X-ray analysis of nano silicon dioxide approved the nano scale for particles. Figure 1 shows a High-resolution transmission electron microscopy (HRTEM) image of the nanoparticle sample. The image shows $\mathrm{SiO}_{2}$ nanoparticles with mean particle diameter of 20-30 nm.

Daily observation for germinating seed continued for ten days. The seedlings were evaluated as described in Seedling Evaluation Handbook (AOSA, 1991). Mean germination time (MGT) was calculated according to Ellis and Roberts (1981) as $\mathrm{MGT}=\sum \mathrm{T} i \mathrm{Ni} / \sum \mathrm{N} i$, where $\mathrm{N} i$ is the number of newly germinated seeds at time $\mathrm{T} i$. Germination rate considered as the reciprocal of the mean germination time (Ranal \& Santana, 2006). Mean daily germination 
(MDG), calculated as the cumulative percentage of full seed germination at the end of the test, divided by the number of days from sowing to the end of the test.

\section{$100 \mathrm{~nm}$}

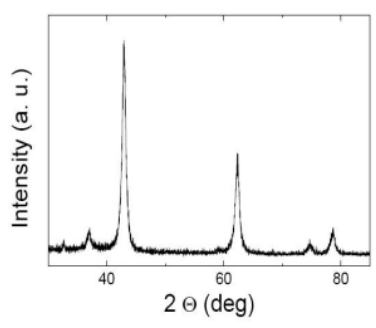

Figure1. Large area The transmission electron microscope (TEM) image and $\mathrm{X}$-Ray diffraction pattern of silicon dioxide nanoparticles.

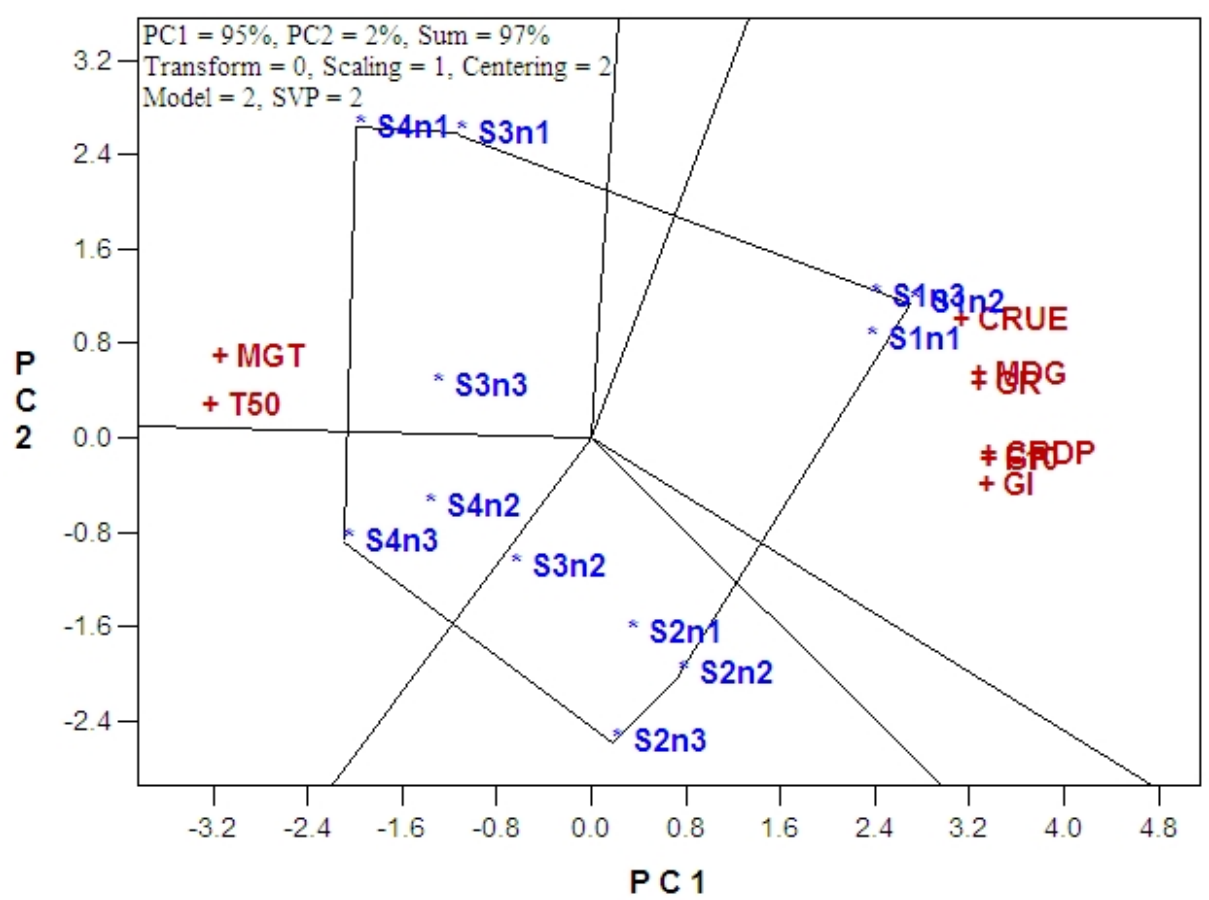

Figure 2. Polygon view for interactive effect of $\mathrm{NaCl} \times$ nano-silicon dioxide by trait biplot, displaying which germination characteristic had the highest values between the different levels of $\mathrm{NaCl}$ and nano-silicon dioxide. 


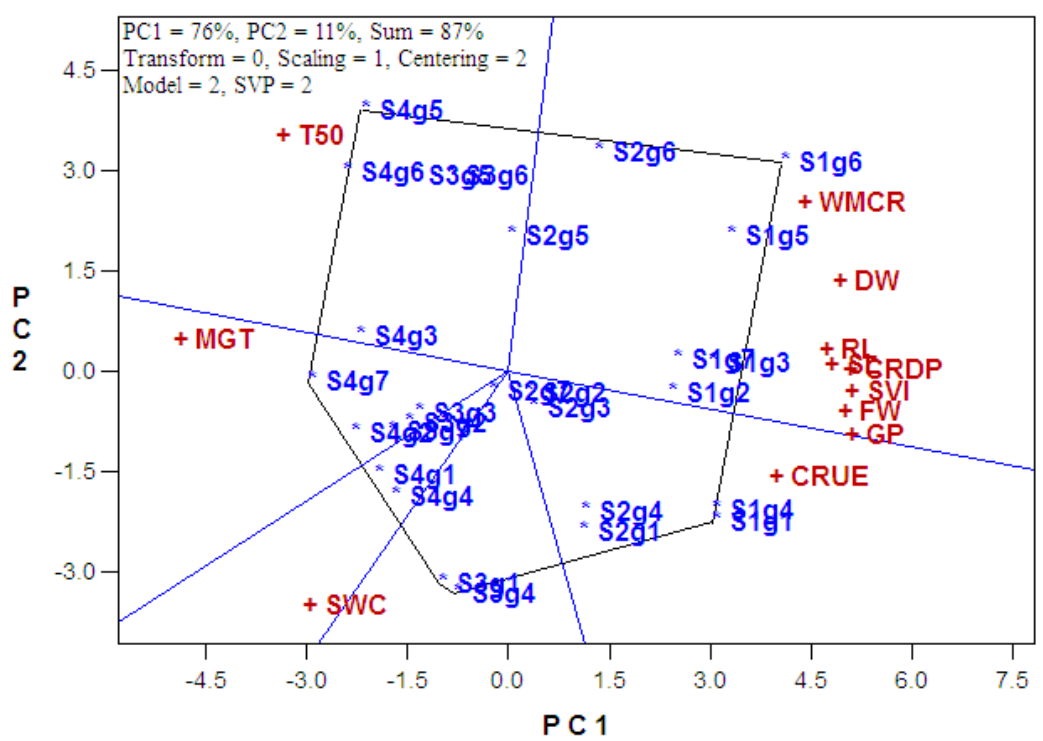

Figure 3. Polygon view for interactive effect of $\mathrm{NaCl} \times$ cutivar by trait biplot, illustrating which germination characteristic had the highest values between the different levels of $\mathrm{NaCl}$ and genotypes.

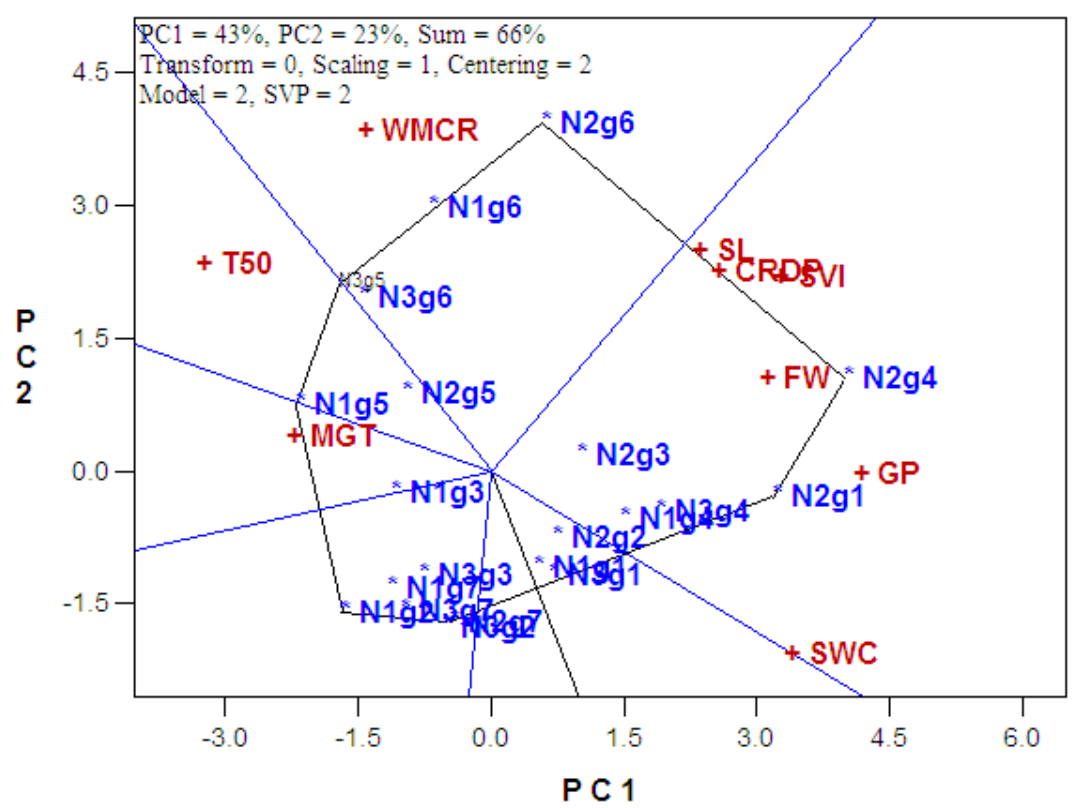

Figure 4. Polygon view for interactive effect of nano-silicon dioxide $\times$ cutivar by trait biplot, illustrating which germination characteristic had the highest values between the different concentration of nano-silicon dioxide and genotypes. 
Temporal distribution of germination can be computed via the germination rate or $T_{50}$ (i.e. the number of days to germination of $50 \%$ of all germinated seeds). $T_{50}$ can be a useful tool for interspecific comparisons on a quantitative basis. $T_{50}$ was calculated according Coolbear et al. (1984) as $T_{50}=\mathrm{t}_{\mathrm{i}}+\left(\mathrm{t}_{\mathrm{j}}-\mathrm{t}_{\mathrm{i}}\right) \times(\mathrm{N} / 2$ $\left.n_{i}\right) /\left(n_{j}-n_{i}\right)$, where $N$ is the final number of germinated seeds while nj and $n_{i}$ are the cumulative number of seeds germinated by adjacent counts at times $t_{j}$ and $t_{i}$, respectively, where $\mathrm{n}_{\mathrm{i}}<\mathrm{N} / 2<\mathrm{n}_{\mathrm{j}}$. The germination index (GI) which expressed as speed of germination was calculated as $\mathrm{GI}=\sum(\mathrm{G} t / \mathrm{T} t)$, where $\mathrm{G} t$ is the accumulated number of germinated seeds on day $t$, and $\mathrm{T} t$ is the time corresponding to $\mathrm{G} t$ in days (Hu et al., 2005). The seed lot having greater germination index is considered to be more vigorous.

Seed reserve utilization was evaluated as delineated by Soltani et al. (2006). After ten days, dry weights of seedlings were determined after drying at $70{ }^{\circ} \mathrm{C}$ in the oven to get the constant weight. The weight of mobilized reserves of cotyledons (WMRC) was determined as the primary dry weight of seed minus the dry weight of the seed residue. Conversion efficiency of mobilized reserves of cotyledons (EMRC) into seedling tissue was estimated by dividing seedling dry weight by the mobilized stored reserves of seed. The ratio of utilized seed reserve to initial seed dry weight was considered as cotyledons reserve depletion percentage (CRDP).

Seed vigour index (SVI) was calculated as explained by Abdul-Baki \& Anderson (1973): SVI = [seedling length $(\mathrm{cm}) \times$ germination percentage]. Reduction of germination (RPG) was determined according to Madidi et al. (2004). Seedling water content (SWC) was calculated as [(seedling fresh weightseedling dry weight)/ seedling dry weight].

All the obtained results were statistically analyzed using Fisher's analysis of variance technique and the least significant difference test (LSD) at 5\% level of probability through the GLM procedure of the Statistical Analysis System. For better analysis of treatment $\times$ trait interaction, the related biplot analysis as TT biplot (Yan, 2001). was used to determine which treatment combination was best and for what trait. In figures of biplot analysis (figure 2-4) the different levels of salinity were shown as S1, S2, S3 and S4 (control, 50, 100, $150 \mathrm{mM}$, respectively), and various concentration of nano-silicon dioxide displayed as $n_{1}$, $\mathrm{n}_{2}$ and $\mathrm{n}_{3}$ (control, 1 and $2 \mathrm{mM}$, respectively). The TT biplots were generated using the standardized values of the traits means based on Model 2; dataset was not transformed (Transform $=0$ ), within-trait standard deviation standardized (Scale $=1)$, and trait-centred (Centering=2) were used. The polygon pattern were according to treatment-focused singular value partitioning $(\mathrm{SVP}=2)$, which is appropriate for visualizing the relationships among traits and treatment combinations. All biplots reported in this research were conducted by using the GGEbiplot software (Yan, 2001). 


\section{RESULTS AND DISCUSSION}

Statistical analysis showed that main effects of $\mathrm{NaCl}, \mathrm{nSiO}_{2}$ and genotype were significant for all of investigated traits. Interactive effect of $\mathrm{NaCl} \times \mathrm{nSiO}_{2}$ was significant for germination percentage (GP), mean germination time (MGT), CRDP (cotyledon reserve depletion percentage), CRUE (cotyledon reserve utilization efficiency), $\mathrm{T}_{50}$; GI (germination index) GR (germination rate), MDG (mean daily germination). Mean comparison of GP between different levels of salinity and $\mathrm{nSiO}_{2}$ revealed that salinity stress caused a significant decrease whereas application of $1 \mathrm{Mm} \mathrm{nSiO}_{2}$ prevented the decrease especially under high $\mathrm{NaCl}$ concentrations (i.e. 100 and $150 \mathrm{mM}$ ). However, the application of $\mathrm{nSiO}_{2}$ could not improve GP under mild and no-stress conditions (Table 1). The highest reduction of germination was recorded under 100 and $150 \mathrm{Mm} \mathrm{NaCl}$ with application of $2 \mathrm{mM} \mathrm{nSiO}_{2}$. This probably refers to inhibitory or toxic effects of $\mathrm{Si}$ at high concentrations. In this context, Wang et al. (2010) and Haghighi et al. (2012) reported that high concentration of Si can resulted in reduced germination. This finding is in agreement with Haghighi et al. (2012) findings which showed that application of same concentration of $\mathrm{nSiO}_{2}$ increased GP of tomato only under salinity stress. However, the findings of the Siddiqui, Al-Whaibi (2014) showed a positive effect of $\mathrm{nSiO}_{2}$ on GP of tomato under stress free condition. The mean comparison of MDG between different levels of $\mathrm{NaCl}$ and $\mathrm{nSiO}_{2}$ revealed that salinity adversely affected $\mathrm{MDG}$ but $\mathrm{nSiO}_{2}$ treatment slightly increase this trait. However, with increasing salinity levels, the beneficially effects of $\mathrm{nSiO}_{2}$ on MGD considerably declined. Evaluation of MGT showed that lowest value was related to stress free condition (control), while under salinity stress application of $1 \mathrm{Mm} \mathrm{nSiO}_{2}$ noticeably decreased the MGT Compared with control (no application) and $2 \mathrm{mM} \mathrm{nSiO}$. This trend also was recognizable by examining the $\mathrm{T}_{50}$ and GR, since application of $1 \mathrm{Mm} \mathrm{nSiO}_{2}$ caused a significant reduction in $\mathrm{T}_{50}$ and improved GR (Table 1). These results further support the findings of Wang et al. (2010) who found that exogenous application of silicon could improve GR and GI of bitter gourd (Momordica charantia L.) under 50 and $100 \mathrm{mM} \mathrm{NaCl}$ concentrations. GI was significantly depressed under $\mathrm{NaCl}$ stresses, and reduced $21.27 \%, 45.71 \%$ and $55.6 \%$ compared to that of the control, respectively. However, the addition of $1 \mathrm{mM} \mathrm{nSiO}{ }_{2}$ significantly alleviated inhibitory effects of $\mathrm{NaCl}$ stress (Table 1). The results indicated that salinity adversely affected both CRDP and CRUE. In addition application of $\mathrm{nSiO}_{2}$ at $1 \mathrm{mM}$ concentration could improve CRDP up to $12 \%$ and $15 \%$ under 100 and 150 $\mathrm{mM} \mathrm{NaCl}$ concentrations, respectively. However, this was not reflected in CRUE that could be due to catabolism of storage reserves to meet the cells required energy demand for alleviating stress effects. In this context, some researchers like as Soltani et al. (2006) and Mohammadi et al. (2011) introduced seed reserve utilization efficiency as a conservative trait which rarely be affected by various factors.

The biplot in Figure 2 explains the data of Interactive effect of $\mathrm{NaCl} \times$ $\mathrm{nSiO}_{2}$ on different evaluated traits. The vertex combined treatment in this study 
was $\mathrm{S}_{1} \mathrm{n}_{2}$ (application $1 \mathrm{mMnSiO}$ under stress free condition) and the highest value of GI, GP, CRDP, MDG and CRUE was obtained from this combined treatment. These results suggest that although the utilization of $\mathrm{nSiO}_{2}$ could partially mitigate the unfavorable effect of $\mathrm{NaCl}$, the application of $\mathrm{nSiO}_{2}$ under no stress condition can be more effective.

Table 1. Effect of different concentration of silicon dioxide nanoparticles and $\mathrm{NaCl}$ on seed germination characteristics of lentil (Lens culinaris).

\begin{tabular}{|c|c|c|c|c|c|c|c|c|c|}
\hline $\begin{array}{l}\mathrm{NaCl} \\
(\mathrm{mM})\end{array}$ & $\mathrm{nSiO}_{2}$ & GP & MGT & CRDP & CRUE & $\mathbf{T}_{50}$ & GI & GR & MDG \\
\hline \multirow{3}{*}{ control } & control & $95.00^{\mathrm{a}}$ & $1.64^{f}$ & $76.01^{\mathrm{b}}$ & $73.56^{\mathrm{a}}$ & $0.81^{\mathrm{de}}$ & $11.43^{\mathrm{ab}}$ & $0.64^{\mathrm{b}}$ & $61.10^{\mathrm{b}}$ \\
\hline & $1 \mathrm{mM}$ & $94.66^{\mathrm{a}}$ & $1.35^{\mathrm{f}}$ & $82.04^{\mathrm{a}}$ & $73.02^{\mathrm{a}}$ & $0.64^{\mathrm{e}}$ & $12.09^{\mathrm{a}}$ & $0.76^{\mathrm{a}}$ & $71.89^{\mathrm{a}}$ \\
\hline & $2 \mathrm{mM}$ & $93.33^{\mathrm{a}}$ & $1.53^{\mathrm{f}}$ & $76.94^{\mathrm{ab}}$ & $73.51^{\mathrm{a}}$ & $0.75^{\mathrm{e}}$ & $11.09^{\mathrm{ab}}$ & $0.68^{\mathrm{b}}$ & $63.60^{\mathrm{b}}$ \\
\hline \multirow{3}{*}{50} & control & $74.33^{\mathrm{b}}$ & $3.68^{\mathrm{d}}$ & $59.52^{\mathrm{c}}$ & $58.89^{\mathrm{b}}$ & $1.37^{\mathrm{cd}}$ & $8.98^{\text {cd }}$ & $0.27^{\mathrm{d}}$ & $20.22^{\text {de }}$ \\
\hline & $1 \mathrm{mM}$ & $77.66^{\mathrm{b}}$ & $2.85^{\mathrm{e}}$ & $59.21^{\mathrm{c}}$ & $59.00^{\mathrm{b}}$ & $1.19^{\mathrm{d}}$ & $9.91^{\mathrm{bc}}$ & $0.37^{\mathrm{c}}$ & $29.47^{\mathrm{c}}$ \\
\hline & $2 \mathrm{mM}$ & $74.66^{\mathrm{b}}$ & $3.28^{\mathrm{de}}$ & $56.50^{\mathrm{c}}$ & $51.74^{\mathrm{bc}}$ & $1.51^{\mathrm{bc}}$ & $8.19^{\mathrm{de}}$ & $0.31^{\text {cd }}$ & $23.08^{\mathrm{cd}}$ \\
\hline \multirow{3}{*}{100} & control & $57.00^{\mathrm{cd}}$ & $5.98^{\mathrm{c}}$ & $37.92^{\mathrm{de}}$ & $59.14^{\mathrm{b}}$ & $2.13^{\mathrm{a}}$ & $5.57^{\mathrm{f}}$ & $0.17^{\mathrm{d}}$ & $9.76^{\mathrm{f}}$ \\
\hline & $1 \mathrm{mM}$ & $62.33^{\mathrm{c}}$ & $4.19^{\mathrm{d}}$ & $42.64^{\mathrm{d}}$ & $50.49^{\mathrm{c}}$ & $1.96^{\mathrm{ab}}$ & $7.17^{\mathrm{ef}}$ & $0.24^{\mathrm{de}}$ & $15.48^{\mathrm{ef}}$ \\
\hline & $2 \mathrm{mM}$ & $52.66^{\mathrm{d}}$ & $5.74^{\mathrm{c}}$ & $37.35^{\text {de }}$ & $49.27^{\mathrm{c}}$ & $2.16^{\mathrm{a}}$ & $6.06^{\mathrm{f}}$ & $0.17^{\text {ef }}$ & $9.24^{\mathrm{f}}$ \\
\hline \multirow{3}{*}{150} & control & $45.00^{\mathrm{e}}$ & $7.63^{\mathrm{a}}$ & $30.94^{\mathrm{f}}$ & $47.97^{\mathrm{c}}$ & $2.36^{\mathrm{a}}$ & $4.53^{g}$ & $0.13^{\mathrm{f}}$ & $6.01^{\mathrm{fg}}$ \\
\hline & $1 \mathrm{mM}$ & $51.33^{\mathrm{d}}$ & $5.48^{\mathrm{c}}$ & $35.68^{\mathrm{e}}$ & $44.64^{\mathrm{cd}}$ & $2.02^{\mathrm{ab}}$ & $5.84^{\mathrm{f}}$ & $0.18^{\mathrm{ef}}$ & $9.69^{f}$ \\
\hline & $2 \mathrm{mM}$ & $43.33^{\mathrm{e}}$ & $6.89^{\mathrm{b}}$ & $32.86^{\text {ef }}$ & $34.03^{\mathrm{e}}$ & $2.32^{\mathrm{a}}$ & $5.01^{\mathrm{fg}}$ & $0.14^{\mathrm{f}}$ & $6.34^{\mathrm{fg}}$ \\
\hline
\end{tabular}

Means sharing the same letter do not differ significantly at $\mathrm{P}=0.05$. GP, germination percentage; MGT, mean germination time (day); CRDP, cotyledon reserve depletion percentage; CRUE, cotyledon reserve utilization efficiency (\%); $\mathrm{T}_{50}$, time to $50 \%$ germination (day); GI, germination index; GR, germination rate; MDG, mean daily germination (\%).

Result of variance analysis revealed that the interactive effect of $\mathrm{NaCl} \times$ genotype was significant for germination percentage (GP), shoot length (SL), root length (RL), seedling fresh weight (FW), seedling dry weight (DW), MGT (mean germination time), CRDP (cotyledon reserve depletion percentage), weight of mobilized reserves of cotyledons (WMRC), CRUE, $\mathrm{T}_{50}$, seed vigour index (SVI) and seedling water content (SWC).

Although the salinity stress significantly decrease GP in all genotypes, G4 (Syrian Local Large) and G1 (PI 299127) had a greater GP than other genotypes (Table 2). Similar to our findings Sidari et al. (2008) showed a great variation as regards the germination percentage depending on the type of lentil cultivar and the applied level of $\mathrm{NaCl}$. Mean comparison of shoot length showed that salinity reduced this traits but the extent of the reduction over the $\mathrm{NaCl}$ levels significantly was different between the genotypes. However, the most reduction was recorded for local check (G7). Assessment of root length showed that under stress free condition and salinity stress the G2 and G7 had the shortest roots. However, under $\mathrm{NaCl}$ stress the longest root were recoded for G4 and G6 (Table 2). Also the highest seedling fresh weight loss over the $\mathrm{NaCl}$ levels was observed for G4 and G6. The rate of change in seedling dry weight was significantly lower than fresh weight between the different $\mathrm{NaCl}$ levels. Nonetheless, the under high salt stress the heaviest seedling was obtained from G6. Evaluation of seedling water content showed that the under $\mathrm{NaCl}$ stress $\mathrm{G} 4$ and $\mathrm{G} 7$ had succulent growth (Table 2). 
Table 2. Comparison of means for germination parameters of lentil (Lens culinaris L.) cultivars exposed to different $\mathrm{NaCl}$ concentration.

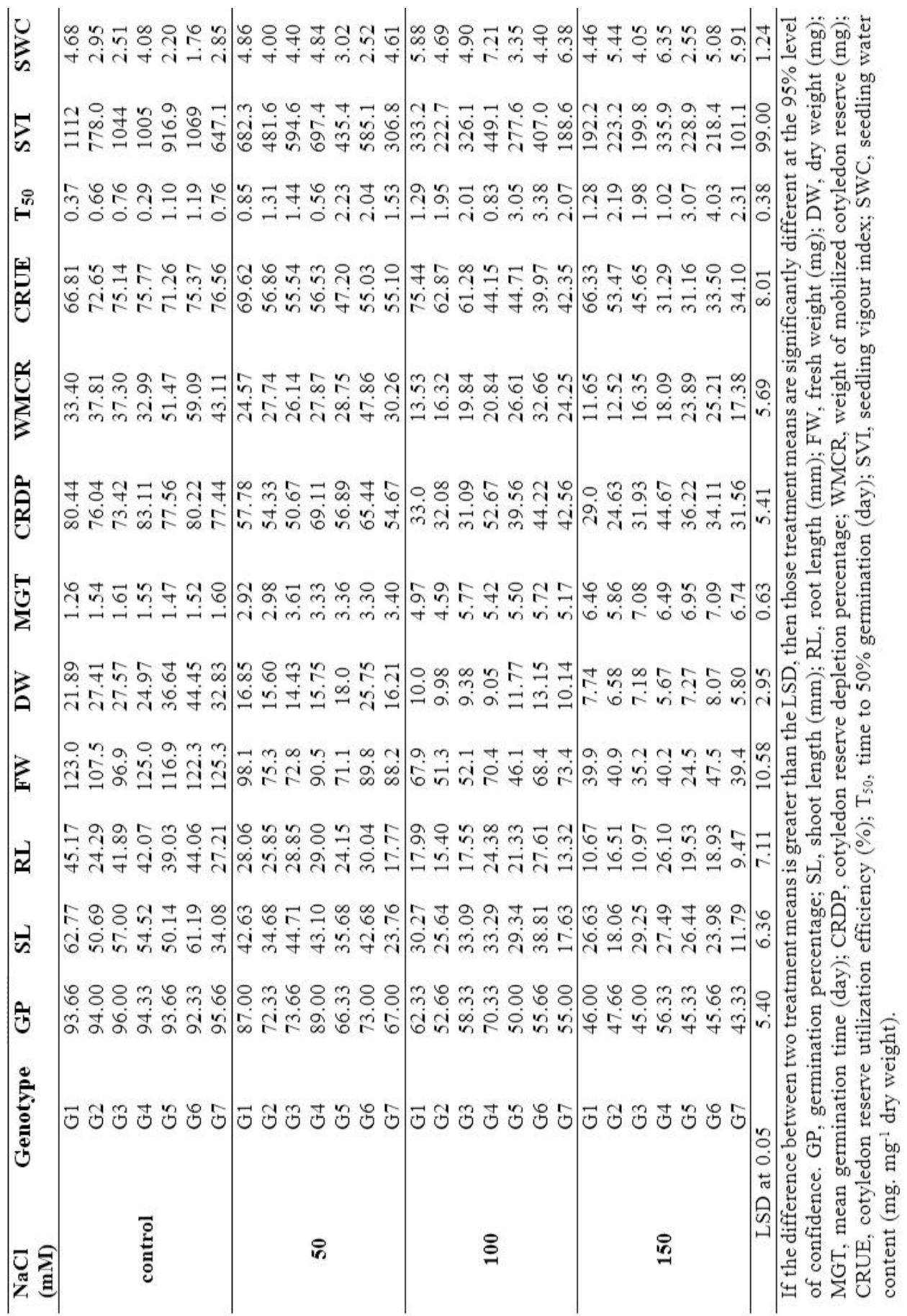


The lowest MGT was recorded for G2, while the highest value was observed for G6. This statue was recognizable by evaluating the $\mathrm{T}_{50}$, where the highest $\mathrm{T}_{50}$ under severe $\mathrm{NaCl}$ stress $(150 \mathrm{mM} \mathrm{NaCl})$ was showed in $\mathrm{G} 6$. Mean comparison of seed vigour index showed that although G1 and G3 had the highest value under stress free condition, under $\mathrm{NaCl}$ stress the best performance was recorded in G4. However, the lowest SVI was recorded for local check. Both cotyledon reserve depletion percentage (CRDP) and weight of mobilized cotyledon reserve (WMCR) adversely affected by $\mathrm{NaCl}$ stress. The highest CRDP under stress condition was observed for G4 and the highest WMCR was recorded for G6. The difference in responses may caused by differences in initial seed weight. Although the G1 had greater seed size, showed the lowest seedling dry weight under severe salt stress. Generally, there are contradictory reports on the benefit of large seeds in producing more vigorous seedling. This also accords with our earlier observations, which showed that seed reserve depletion and weight of mobilized seed reserve of wheat cultivars decreased in a different manner with increasing salt intensity (Soltani et al., 2006).

The biplot in Figure 3 illustrates the combined effects of the genotype and the salt factors on different traits. The result revealed that the most important vertex between the combined treatments was $S_{1} G_{6}$ (Jordanian line under stress free condition) that showed the highest value of WMCR, DW, RL, SL, GP, GR, FW, SVI and CRDP. However, the highest value of T50 and MGT was exhibited for vertex of $S_{4} G_{5}$ and $S_{4} G_{7}$. It shows that under high salinity stress $(150 \mathrm{mM})$ germination of cv. Precoz and Iranian local check compared with other genotypes considerably delayed.

The interaction effect of $\mathrm{nSiO}_{2}$ and genotype was significant germination percentage (GP), shoot length (SL), seedling fresh weight (FW), mean germination time (MGT), cotyledon reserve depletion percentage (CRDP), weight of mobilized reserves of cotyledons (WMRC), $\mathrm{T}_{50}$, seed vigour index (SVI) and seedling water content (SWC). Te highest GP, FW, SVI and SWC was recorded for $\mathrm{G} 1$ and $\mathrm{G} 4$ by application of $1 \mathrm{mM} \mathrm{nSiO}_{2}$ (Table 3). Moreover, the biplot in Figure 4 clearly confirm the superiority of G1 and G4. Result showed that in the most of the evaluated characteristics applications of $2 \mathrm{mM} \mathrm{nSiO}$ caused a significant reduction in all genotypes (Table 3).. This trend also previously reported by Wang et al. (2010) and Haghighi et al (2012). Mean comparison of seed reserves mobilization characteristics (CRDP and WMRC) revealed that the most mobilization value was recorded for G4 and G6 with application of $1 \mathrm{mMnSiO}$. Moreover the lowest value of MGT and $\mathrm{T}_{50}$ were observed $\mathrm{G} 1$ and $\mathrm{G} 4$ by same $\mathrm{nSiO}_{2}$ treatment, indicating the enhancing effects of $\mathrm{nSiO}_{2}$ on germination velocity and temporal distribution of seed germination. Application of $1 \mathrm{mM} \mathrm{nSiO}{ }_{2}$ could significantly improve SVI in G1, G4 and G6 (Table 3). 
Table 3. Average values of germinations traits of lentil (Lens culinaris L.) cultivars under application of different concentrations of nano-silicon dioxide.

\begin{tabular}{|c|c|c|c|c|c|c|c|c|c|c|}
\hline $\mathrm{nSiO}_{2}$ & Genotype & GP & SL & FW & MGT & CRDP & WMCR & $T_{50}$ & SVI & SWC \\
\hline \multirow{7}{*}{ control } & G1 & 70.66 & 41.25 & 71.00 & 4.89 & 45.92 & 18.70 & 1.06 & 591.2 & 4.56 \\
\hline & G2 & 66.00 & 28.00 & 58.01 & 4.37 & 46.85 & 23.75 & 1.51 & 360.0 & 2.98 \\
\hline & G3 & 69.66 & 40.13 & 52.10 & 4.68 & 44.76 & 23.34 & 1.62 & 544.6 & 2.33 \\
\hline & G4 & 76.00 & 31.34 & 81.09 & 4.82 & 61.83 & 24.40 & 0.67 & 539.5 & 4.89 \\
\hline & G5 & 65.33 & 33.71 & 60.49 & 5.11 & 48.42 & 32.34 & 2.57 & 446.4 & 2.67 \\
\hline & G6 & 65.00 & 42.28 & 84.38 & 4.71 & 55.92 & 41.32 & 2.67 & 553.5 & 3.55 \\
\hline & G7 & 64.66 & 19.53 & 81.24 & 4.56 & 54.00 & 30.20 & 1.58 & 293.9 & 4.50 \\
\hline \multirow{7}{*}{$1 \mathrm{mM}$} & G1 & 78.33 & 44.08 & 95.00 & 2.95 & 53.58 & 21.41 & 0.83 & 664.6 & 5.62 \\
\hline & G2 & 70.00 & 37.67 & 78.47 & 3.06 & 48.76 & 24.92 & 1.47 & 490.6 & 4.67 \\
\hline & G3 & 71.00 & 42.92 & 80.20 & 4.22 & 51.28 & 25.89 & 1.36 & 590.4 & 4.71 \\
\hline & G4 & 81.00 & 45.94 & 92.19 & 3.25 & 66.92 & 27.08 & 0.59 & 712.8 & 6.01 \\
\hline & G5 & 64.66 & 35.32 & 73.79 & 3.42 & 49.83 & 33.49 & 2.50 & 468.6 & 3.37 \\
\hline & G6 & 69.00 & 44.49 & 88.89 & 3.99 & 62.75 & 45.87 & 2.22 & 627.2 & 3.50 \\
\hline & G7 & 66.00 & 21.33 & 86.19 & 3.39 & 51.08 & 28.73 & 1.71 & 294.4 & 5.13 \\
\hline \multirow{8}{*}{$2 \mathrm{mM}$} & G1 & 68.00 & 36.39 & 80.73 & 3.87 & 50.67 & 22.25 & 0.95 & 483.9 & 4.72 \\
\hline & $\mathrm{G} 2$ & 63.00 & 34.74 & 69.68 & 3.79 & 44.70 & 22.10 & 1.60 & 428.5 & 5.15 \\
\hline & G3 & 64.00 & 40.00 & 60.58 & 4.65 & 44.28 & 22.49 & 1.66 & 488.4 & 4.85 \\
\hline & G4 & 75.00 & 41.51 & 71.40 & 4.54 & 58.42 & 23.36 & 0.78 & 613.7 & 5.95 \\
\hline & G5 & 61.00 & 37.18 & 59.66 & 4.42 & 59.42 & 39.71 & 2.02 & 479.1 & 2.31 \\
\hline & G6 & 65.33 & 38.22 & 72.87 & 4.52 & 49.33 & 36.41 & 3.09 & 528.9 & 3.26 \\
\hline & G7 & 65.00 & 24.58 & 77.25 & 4.73 & 49.58 & 27.30 & 1.72 & 344.4 & 5.15 \\
\hline & at 0.05 & 5.40 & 6.35 & 10.58 & 0.63 & 8.77 & 5.69 & 0.38 & 99.00 & 1.24 \\
\hline
\end{tabular}

GP, germination percentage; SL, shoot length $(\mathrm{mm})$; FW, fresh weight (mg); MGT, mean germination time (day); CRDP, cotyledon reserve depletion percentage; WMCR, weight of mobilized cotyledon reserve (mg); $\mathrm{T}_{50}$, time to $50 \%$ germination (day); SVI, seedling vigour index; SWC, seedling water content (mg. $\mathrm{mg}^{-1}$ dry weight).

\section{DISCUSSION}

Results of current study showed that lentil germination and early growth was considerably inhibited by increase of $\mathrm{NaCl}$ concentration. The decline even was evident under mild salt stress $(50 \mathrm{mM})$ for all of the investigated traits. It may refer to this point that threshold of salinity tolerance for lentil germination is lower than $50 \mathrm{mM}$. The Inhibition of seed germination under salt conditions could be due to decreased water content, which influence the synthesis and activity of different hydrolytic enzymes and finally restrict the mobilization of cotyledon reserves for developing embryo axis (Ashraf \& Foolad, 2005). In the same Sidari et al. (2008) reported that $\mathrm{NaCl}$ stress can decrease activities of the main enzymes involved in the germination process like as $\alpha$-amylase, $\beta$-amylase and $\alpha$-glucosidase in different lentil genotypes. The results of this study amplify those of El-Monem and Sharaf (2008) and Karajeh et al. (2003). Furthermore in this study lentil genotypes showed a different salinity tolerance. These differences could be partly caused by ion discrimination ability of tolerant genotypes to limit influx of $\mathrm{Na}^{+}$and $\mathrm{Cl}^{-}$ions to embryo cells (Petruzzelli et al. 1991). Under salinity stress ion toxicity is the result of substitution of $\mathrm{K}^{+}$by $\mathrm{Na}^{+}$ 
in biochemical reactions, and $\mathrm{Na}^{+}$and $\mathrm{Cl}^{-}$induced conformational modifications in both functional and structural proteins.

Mobilization of cotyledon reserves to the developing embryo is a crucial process for seedling growth. Result revealed that seedling dry weight was declined with salinity in all cultivars and under both $\mathrm{nSiO}_{2}$ levels and this reduction closely was associated with weight of mobilized reserves of cotyledons (WMRC). Consequently, it can be suggestible that susceptible component of seedling growth is the WMRC and improvement of this trait can be potential target for lentil breeding programs. The existence of genetic variation between the investigated genotypes offers a valuable source for studying the mechanism of salt tolerance.

Our result indicated that genotypes originated from Mexico, Syria and Jordan showed better performance compared to other genotypes under salinity stress. A glimpse into the region's weather shows that arid and semiarid lands cover most parts of these countries. It has been suggested that one the main management issues involved in lentil production in saline area are the selection of genotypes adapted to the salinity level of the soil. It is clear that there is a close relationship between the rank of lentil genotypes, based on germination and vegetative growth under salinity stress and rank of the same lines grown under field conditions (Jana \& Slinkard, 1979; El-Monem \& Sharaf, 2008).

Furthermore, result of current study also showed that $\mathrm{nSiO}_{2}$ treatment could alleviant adverse effect of $\mathrm{NaCl}$ on germination and seedling early growth. Also germination of lentil seeds is promoted in the presence of $\mathrm{nSiO}_{2}$ under stress free condition. In the former study the authors found that $\mathrm{Si}$ can induce the salinity tolerance through formation of complexes with $\mathrm{Na}$ in roots (Ahmad et al., 1992), protection of plant tissues from reactive oxygen species (ROS) by an enhancing in the activity of ROS scavenging enzymes and protection of plasma membranes (Wang et al., 2010), stimulation of the activity of $\mathrm{H}^{+}$-ATPase (Liang et al., 2003). Application of $\mathrm{Si}$ can reduce $\mathrm{Na}^{+}$content both in shoots and roots and can maintain a highe $\mathrm{K}^{+} / \mathrm{Na}^{+}$ratio (Zuccarini, 2008). Also the same author revealed that the use of $\mathrm{Si}$ could not alternate the allocation pattern of $\mathrm{Cl}^{-}$in common bean (Phaseolus vulgaris) plant.

It seems that these positive effects can be increased by application of nanoscale silicon particle, because of its highly reactive surface-to-volume ratio property and structural flexibility. The presence of NPs on the root surface could alter the surface chemistry of the root such that it affects how the roots interact with their environment. Improving effect of $\mathrm{nSiO}_{2}$ on seedling growth under salinity stress corroborates the theory according to which Si could alleviate the salt stress effects by moderately inhibiting the apoplastic transport, which is responsible for the entry of the main part of sodium cation through plant roots (Garcia et al., 1997). Seed germination and root elongation are considered as the widely used acute phytotoxicity tests with susceptibility for unstable materials and sensitivity (Munzuroglu et al., 2002). Although $\mathrm{SiO}_{2}$ nano particles had been showed no intensive toxic effect on germination and growth of different plants 
spices, in current study its higher concentrations resulted in decrease of germination and root elongation. The inhibitory influence with higher nanoparticle concentration reveals the need for judicious utilization of these particles in such applications. However, comprehensive information about the role of nano-sized engineered materials on different aspect of seed germination at the subcellular and molecular level is still absent.

\section{CONCLUSIONS}

The current study aimed to study the effect of silicon dioxide nanoparticles on germination of lentil genotypes under saline condition. Seed germination and early seedling growth are generally the stages most susceptible to salt stress. The results of revealed that salinity significantly delayed germination and higher salt concentrations reduced the percentage of germinated seeds and seedling growth parameters. However, application the of $1 \mathrm{mM}$ nano-silicon dioxide $\left(\mathrm{nSiO}_{2}\right)$ alleviate the adverse effect of $\mathrm{NaCl}$ and considerably improved seed performance and provided faster and synchronized germination. Finding of this experiment refer to this point that in addition to the techniques already mentioned (e.g. presowing seed treatments) agriculturists can employ alternative approaches to alleviate adverse effects of salt stress on plants at different developmental stages. This approach involves application of favorable nanoparticles to improve germination, early seedling growth, and final crop yield under salt stress. Result showed that suitable concentration of nano- $\mathrm{SiO}_{2}$ can be used as a directly utilizable source for seedling. Additionally, silicon dioxide nanoparticles can be applied by indirect methods such as seed coating. However, in order to recognize the critical concentration of nanoparticles in agriculture, it is essential to analyze penetration and transport of nanoparticles in the plants. Overall, results clearly indicate that there is genetic variation for salt tolerance in lentil at germination and early growth stages, and the best performance was observed from exotic genotypes originated from Mexico, Syria and Jordan.

\section{ACKNOWLEDGMENTS}

The authors thank Dr. Wei-Kai Yan (Eastern Cereal Oilseed Research Center of Agriculture and Agri-Food Canada) for the gift of a time-limited version of GGEbiplot as "testBiplotxlsx".

\section{REFERENCES}

Abdul-Baki, A. A., Anderson J. D. 1973: Relationship between decarboxylation of glutamic acid and vigor in soybean seed. Crop Science, 13 (2): 227-232.

Al-Aysh, F., Al-Abdalla, N., Al-Nabelssi, A. 2014. Phenotypic adaptability and stability of macrosperma lentil landraces in dara'a govrenorate, syria. Poljoprivreda i Sumarstvo, 60(1), 169-178.

Ashraf, M., Foolad, M. R. 2005: Pre-Sowing Seed Treatment-A Shotgun Approach to Improve Germination, Plant Growth, and Crop Yield Under Saline and Non-Saline Conditions. Advances in Agronomy, 88: 223-271. 
Association of Official Seed Analysis (AOSA). 1991: Rules for testing seeds. Seed Science and Technology, 12:18-19.

Coolbear, P., Francis, A., Grierson, D. 1984: The effect of low temperature pre-sowing treatment on the germination performance and membrane integrity of artificially aged tomato seeds. Journal of Experimental Botany, 35 (11): 1609-1617.

El Madidi, S. A. D., El Baroudi, B. R., Aameur, F. B. 2004: Effects of salinity on germination and early growth of barley (Hordeum vulgare L.) cultivars. International Journal of Agriculture \& Biology, 6(5): 767-770.

Ellis, R. H., Roberts, E. H. 1981: The quantification of ageing and survival in orthodox seeds. Seed Science and Technology (Netherlands), 9: 373-409

El-Monem, A., Sharaf M. 2008: Tolerance of five genotypes of lentil to NaCl-salinity stress. New York Science Journal, 1: 70-80.

Garcia, A., Rizzo, C. A., Ud-Din, J., Bartos, S. L., Senadhira, D., Flowers, T. J., Yeo, A. R. 1997: Sodium and potassium transport to the xylem are inherited independently in rice, and the mechanism of sodium: potassium selectivity differs between rice and wheat. Plant, Cell and Environment, 20 (9): 1167-1174.

Gürsoy, S., Özaslan, C., Urgun, M., Kolay, B., Koç, M. 2014. The effect of sowing time, tillage system and herbicides on weed species density, weed biomass and yield of lentil within a lentil-wheat sequence. Poljoprivreda i Sumarstvo, 60(3), 73-84.

Haghighi, M., Afifipour, Z., Mozafarian, M. 2012: The effect of N-Si on tomato seed germination under salinity levels. Journal of Biological and Environmental Science, 6, 87-90.

Hu, J., Zhu, Z. Y., Song, W. J., Wang, J. C., Hu, W. M. 2005: Effects of sand priming on germination and field performance in direct-sown rice (Oryza sativa L.). Seed Science and Technology, 33 (1): 243-248.

Jana, M. K., Slinkard, A. E. 1979: Screening for salt tolerance in lentils. LENS Newslett, 6: 25-27.

Janmohammadi, M. 2012. Alleviation the adverse effect of cadmium on seedling growth of greater burdock (Aractium lappal L.) through pre-sowing treatments. Poljoprivreda i Sumarstvo, 56(1-4), 55-69.

Karajeh F., Hamdy A., Bruggeman A., Touchan H., Oweis T. 2003. In vitro salinity tolerance screening of some legumes and forages cultivars. Regional Action Programme (RAP): Water resources management and water saving in irrigated agriculture (WASIA PROJECT), 163-169.

Katerji, N., Van Hoorn, J. W., Hamdy, A., Mastrorilli, M., Oweis, T., Erskine, W. 2001: Response of two varieties of lentil to soil salanity. Agricultural water management, 47(3): 179-190.

Liang, Y., Sun W., Zhu, Y.G., Christie, P. 2007: Mechanisms of silicon mediated alleviation of abiotic stresses in higher plants: a review. Environmental Pollution, 147: 422-428.

Liang, Y., Chen, Q., Liu Q., Zhang W., Ding R. 2003: Exogenous silicon (Si) increases antioxidant enzyme activity and reduces lipid peroxidation in roots of salt-stressed barley (Hordeum vulgare L.). Journal of plant physiology, 160 (10): 1157-1164.

Ma, J.F., Yamaji, N. 2006: Silicon uptake and accumulation in higher plants. Trends in Plant Science, 11: 342-397.

Ma, J. F. 2004. Role of silicon in enhancing the resistance of plants to biotic and abiotic stresses. Soil Science and Plant Nutrition, 50(1): 11-18. 
Martinez-Beltran, J., Manzur, C.L. 2005: Overview of salinity problems in the world and FAO strategies to address the problem. In: Proceedings of the International Salinity Forum, Riverside, California, April, p. 311-313.

Mohammadi, H., Soltani, A., Sadeghipour, H. R., Zeinali, E. 2011: Effects of seed aging on subsequent seed reserve utilization and seedling growth in soybean. International Journal of Plant Production, 5 (1): 65-70.

Munzuroglu, O., Geckil, H. 2002: Effects of metals on seed germination, root elongation, and coleoptile and hypocotyl growth in Triticum aestivum and Cucumis sativus. Archives of Environmental Contamination and Toxicology, 43 (2): 203-213.

Petruzzelli, L., Melillo, M. T., Bleve-Zacheo, T., Marano, B., Taranto, G. 1991: The sensitivity of germinating Triticum durum L. kernels to saline environment. Seed Science Research, 1 (2): 105-111.

Rains, D. W., Epstein, E., Zasoski, R. J., Aslam, M. 2006: Active silicon uptake by wheat. Plant and Soil, 280 (1-2): 223-228.

Ranal, M. A., Santana, D. G. D. 2006: How and why to measure the germination process? Brazilian Journal of Botany, 29 (1): 1-11.

Sabaghnia, S., Janmohammadi, M. 2014: Graphic analysis of nano-silicon by salinity stress interaction on germination properties of lentil using the biplot method. Poljoprivreda i Sumarstvo, 60 (3): 29-40.

Sidari, M., Santonoceto, C., Anastasi, U., Preiti, G., Muscolo, A. 2008: Variations in four genotypes of lentil under NaCl-salinity stress. American Journal of Agricultural and Biological Sciences, 3 (1): 410.

Siddiqui, M.H., Al-Whaibi, M.H. 2014: Role of nano-SiO $\mathrm{Sin}_{2}$ germination of tomato (Lycopersicum esculentum seeds Mill.). Saudi Journal of Biological Sciences, 21 (1): 13-17.

Soltani, A., Gholipoor, M., Zeinali, E. 2006: Seed reserve utilization and seedling growth of wheat as affected by drought and salinity. Environmental and Experimental Botany, 55(1): 195-200.

Wang, X. D., Ou-yang, C., Fan, Z., Gao, S., Chen, F., Tang, L. 2010: Effects of exogenous silicon on seed germination and antioxidant enzyme activities of Momordica charantia under salt stress. Journal of Animal and Plant Science, 6:700-708.

Wang, X., Wei, Z., Liu, D., Zhao, G. 2011: Effects of $\mathrm{NaCl}$ and silicon on activities of antioxidative enzymes in roots, shoots and leaves of alfalfa. African Journal of Biotechnology, 10: 545-549.

Yan, W. 2001: GGEbiplot-A Windows application for graphical analysis of multienvironment trial data and other types of two-way data. Agronomy Journal, 93 (5): 1111-1118.

Zuccarini, P. 2008: Effects of silicon on photosynthesis, water relations and nutrient uptake of Phaseolus vulgaris under $\mathrm{NaCl}$ stress. Biologia Plantarum, 52 (1): 157 160. 